\title{
Riverine transport of biogenic elements to the Baltic Sea - past and possible future perspectives
}

\author{
C. Humborg ${ }^{1,4}$, C.-M. Mörth ${ }^{2,4}$, M. Sundbom ${ }^{1}$, and F. Wulff ${ }^{3,4}$ \\ ${ }^{1}$ Dept. of Applied Environmental Science, Stockholm University, 10691 Stockholm, Sweden \\ ${ }^{2}$ Dept. of Geology \& Geochemistry, Stockholm University, 10691 Stockholm, Sweden \\ ${ }^{3}$ Dept. of Systems Ecology, Stockholm University, 10691 Stockholm, Sweden \\ ${ }^{4}$ Baltic Nest Institute, Stockholm University, 10691 Stockholm, Sweden
}

Received: 24 April 2007 - Published in Hydrol. Earth Syst. Sci. Discuss.: 23 May 2007

Revised: 3 September 2007 - Accepted: 17 September 2007 - Published: 26 September 2007

\begin{abstract}
The paper reviews critical processes for the landsea fluxes of biogenic elements $(\mathrm{C}, \mathrm{N}, \mathrm{P}, \mathrm{Si})$ in the Baltic Sea catchment and discusses possible future scenarios as a consequence of improved sewage treatment, agricultural practices and increased hydropower demand (for $\mathrm{N}, \mathrm{P}$ and $\mathrm{Si}$ ) and of global warming, i.e., changes in hydrological patterns (for C). These most significant drivers will not only change the total amount of nutrient inputs and fluxes of organic and inorganic forms of carbon to the Baltic Sea, their ratio (C:N:P:Si) will alter as well with consequences for phytoplankton species composition in the Baltic Sea. In summary, we propose that $\mathrm{N}$ fluxes may increase due to higher livestock densities in those countries recently acceded to the $\mathrm{EU}$, whereas $\mathrm{P}$ and $\mathrm{Si}$ fluxes may decrease due to an improved sewage treatment in these new EU member states and with further damming and still eutrophic states of many lakes in the entire Baltic Sea catchment. This might eventually decrease cyanobacteria blooms in the Baltic but increase the potential for other nuisance blooms. Dinoflagellates could eventually substitute diatoms that even today grow below their optimal growth conditions due to low Si concentrations in some regions of the Baltic Sea. C fluxes will probably increase from the boreal part of the Baltic Sea catchment due to the expected higher temperatures and heavier rainfall. However, it is not clear whether dissolved organic carbon and alkalinity, which have opposite feedbacks to global warming, will increase in similar amounts, because the spring flow peak will be smoothed out in time due to higher temperatures that cause less snow cover and deeper soil infiltration.
\end{abstract}

Correspondence to: C. Humborg

(christoph.humborg@itm.su.se)

\section{Introduction}

The Baltic Sea is a semi enclosed basin with water residence time of some 30 years which makes this estuarine system highly susceptible to changes in riverine loads of biogenic elements $(\mathrm{C}, \mathrm{N}, \mathrm{P}, \mathrm{Si})$. Two major drivers, i.e., the changes in life style in the new EU member states (Poland, Estonia, Latvia and Lithuania) as well as in Russia and global warming, will significantly alter the transport of biogenic elements to the Baltic Sea in the near future. These changes can be expected to be much more severe compared to the variations in riverine fluxes observed over the last 35 years (HELCOM, 2004), because changes in life style translate directly into anthropogenic nutrient emissions and riverine fluxes (Nixon, 1995; Howarth et al., 1996; Boyer et al., 2002) and the foreseen changes in temperatures and rainfall will alter the hydrological patterns in the catchment fundamentally (Graham, 2004). The aim of this paper is first to summarize the current knowledge on riverine nutrient and carbon fluxes in the Baltic Sea catchment, i.e., to describe leading environmental variables that drive these fluxes, and secondly to discuss future scenarios on possible changes in N, P and Si land-sea fluxes as result of the adoption of EU life styles and possible changes of $\mathrm{C}$ fluxes as a result of climate change. In contrast to regional assessments using national data sets with varying quality and evaluation tools summarized by the HELCOM pollution load compilations (HELCOM, 2004) we will use a more consistent data set on nutrient and carbon loads as well as water discharge and will use modelling tools to simulate possible future TN and TP fluxes compiled by the MARE project. This will facilitate a comparison of riverine nutrient transports between Baltic Sea sub-catchments that differ substantially both in terms of climate, hydrology and human impacts. We will briefly summarize these tools, however, for detailed information on data used and the

Published by Copernicus Publications on behalf of the European Geosciences Union. 


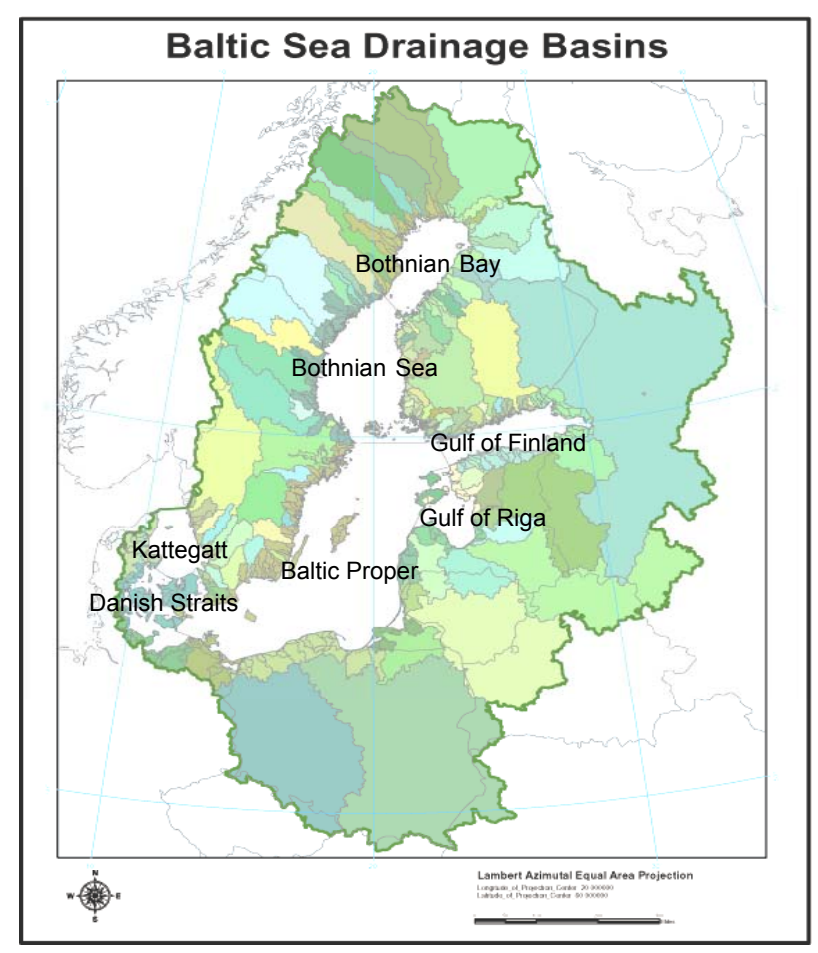

Fig. 1. Map over the Baltic Sea catchment and main watershed areas.

modelling approach the reader is referred to the MARE website (www.mare.su.se) and recent publications by (Mörth et al., 2007) and (Wulff et al., 2007).

The drainage basin of the Baltic Sea can be divided into a northern boreal part that drains into the Gulf of Bothnia (Bothnian Bay=BB and Bothnian Sea = BS) and a southeastern part that drains into the rest of the Baltic Sea (Baltic proper $=$ BP, Gulf of Finland $=$ GF, Gulf of Riga $=$ GR, Danish Sounds $=$ D, Kattegat $=$ KT; Figs. 1 and 2). The northern watersheds are generally densely populated and less eutrophic compared with the more populous and eutrophic watersheds of the southeast. The dominating land cover in the north is boreal forest and wetlands. The watersheds of the southeast are dominated by agriculture (Table 1; Fig. 2). River nutrient loads, especially from the Oder, Vistula, Daugava and Nemunas Rivers, contribute most to riverine eutrophication of the central and southern basins of the Baltic Sea (Stålnacke et al., 1999a). Coastal point sources are more significant for coastal eutrophication of the northern basins and the northeastern Gulf of Finland. The most significant coastal point sources are major cities such as St. Petersburg, Helsinki and Stockholm (HELCOM, 2004). The largest mass fluxes of nutrients come from the rivers Oder and Vistula, draining Poland and its 38 million inhabitants, about half of the population of the entire Baltic Sea catchment (Hannerz et al., 2006).
In contrast to the north-south division of the watersheds, based on natural settings and landscape variables, an eastwest distinction can be made for the socio-political characteristics of the watersheds. Most riparian countries are now members of the European Union, although the entry of Poland, Lithuania, Latvia and Estonia is relatively recent and their economies can be described as transitional. Russia has also shifted from a centralised economy. These socio-political changes are likely to have an impact on nutrient land-sea fluxes, primarily through effects on agriculture, since the demand of animal protein will probably increase with economical growth that is indicated by relationship between animal protein consumption and the gross national productivity (Fig. 3).

\section{Results and discussion}

\subsection{Past and possible future changes in $\mathrm{N}$ and $\mathrm{P}$ fluxes}

The overall nutrient load to the Baltic Sea has increased by a factor 2.4 and 3.1 for total nitrogen (TN) and total phosphorus (TP), respectively, over the last 100 years (Schernewski et al., 2005). Significant changes in nutrient loads could be expected especially from transitional countries (Poland and the Baltic States, Czech Republic, Belarus and Russia) due to dramatic socio-economical changes. The use of fertilizer and livestock densities decreased dramatically following the economic breakdown in 1990 (Figs. 4a and b; Löfgren et al., 1999; Stålnacke et al., 2003; Vagstad et al., 2004; Eriksson et al., 2007). However, the overall nutrient load to the Baltic Sea has not changed significantly during the last 30 years (Fig. 5; HELCOM, 2004, and references therein; Stålnacke et al., 1999b) although recently decreasing trends in $\mathrm{N}$ and $\mathrm{P}$ concentrations of several minor rivers have been reported (Iital et al., 2005; Kronvang et al., 2005). Interestingly, rivers draining countries with a large $\mathrm{N}$-surplus - that is all $\mathrm{N}$ added to a hectare sown area such as fertilizer and manure, atmospheric deposition and agricultural imports as feed minus all outputs such as agricultural export and human consumption (Löfgren et al., 1999; Campling et al., 2005) - actually showed decreasing TN and TP river concentrations after the collapse of the agricultural sector. Iital et al. (2005) reported decreasing trends in $\mathrm{N}$ concentrations of 20 Estonian rivers immediately after the drop in inorganic and organic fertilizer use from about $200 \mathrm{~kg} \mathrm{ha}^{-1} \mathrm{yr}^{-1}$ to $<50 \mathrm{~kg} \mathrm{ha}^{-1} \mathrm{yr}^{-1}$. In these parts of the Baltic States agricultural production was intense due to meat production that was exported to the former Soviet Union (Löfgren et al., 1999). However, these rivers are not significant in terms of nutrient mass flux to the Baltic Sea, because all Estonian rivers draining into the Baltic Sea contribute only $4 \%$ to the TN and TP load (Table 2). Similarly, reductions in N surplus of the Danish agriculture from about 130 to $80 \mathrm{~kg} \mathrm{ha}^{-1} \mathrm{yr}^{-1}$ and subsequent decrease in river nutrient concentrations (Kronvang et al., 
Table 1. Baltic Sea basin characteristics indicated as population, population distribution and land class areas to each of the Baltic Sea basins; Bothnian Bay (BB), Baltic Proper (BP), Bothnian Sea (BS), Gulf of Finland (GF), Gulf of Riga (GR), Danish Sounds (DS), Kattegat (KT) and to the total Baltic Sea.

\begin{tabular}{ccccccccccccccc}
\hline Basin & Population & $\begin{array}{c}\text { Urban } \\
\%\end{array}$ & $\begin{array}{c}\text { Rural } \\
\%\end{array}$ & $\begin{array}{c}\text { Catchment Area } \\
\text { ha }\end{array}$ & $\begin{array}{c}\text { Deciduous } \\
\text { ha }\end{array}$ & $\begin{array}{c}\text { Coniferous } \\
\text { ha }\end{array}$ & $\begin{array}{c}\text { Mixed Forest } \\
\text { ha }\end{array}$ & $\begin{array}{c}\text { Herbacous } \\
\text { ha }\end{array}$ & $\begin{array}{c}\text { Wetlands } \\
\text { ha }\end{array}$ & $\begin{array}{c}\text { Cultivated } \\
\text { ha }\end{array}$ & $\begin{array}{c}\text { Bare } \\
\text { ha }\end{array}$ & $\begin{array}{c}\text { Water } \\
\text { ha }\end{array}$ & $\begin{array}{c}\text { Snow and Ice } \\
\text { ha }\end{array}$ & $\begin{array}{c}\text { Artificial } \\
\text { ha }\end{array}$ \\
\hline BB & 1320010 & 47.7 & 52.3 & 26362519 & 787625 & 11433919 & 7197350 & 1400056 & 2373819 & 1075175 & 609163 & 1412081 & 40306 & 33025 \\
BP & 54861680 & 56.8 & 43.2 & 57153463 & 1300206 & 10142531 & 5713819 & 4789506 & 250044 & 32775738 & 2863 & 1369281 & 0 & 809475 \\
BS & 2393152 & 39.4 & 60.6 & 22637213 & 452144 & 13487719 & 4440944 & 691863 & 737250 & 1091388 & 168194 & 1458981 & 275 & 108456 \\
DS & 5220245 & 84.6 & 15.4 & 2883425 & 34538 & 73606 & 79219 & 135056 & 10550 & 2265781 & 0 & 134538 & 0 & 150138 \\
GF & 12364198 & 67.0 & 33.0 & 43110463 & 1282219 & 18592269 & 7614144 & 382238 & 183844 & 8694344 & 0 & 6143138 & 0 & 218269 \\
GR & 3970124 & 45.7 & 54.3 & 13378794 & 796344 & 2234406 & 2253125 & 905838 & 58988 & 6794231 & 0 & 255281 & 0 & 80581 \\
KT & 2920856 & 57.8 & 42.2 & 7934431 & 156938 & 3410575 & 1225913 & 202656 & 78431 & 1767013 & 7600 & 968381 & 0 & 116925 \\
\hline SUM & 83050265 & 57.0 & 43.0 & 173460306 & 4810013 & 59375025 & 28524513 & 8507213 & 3692925 & 54463669 & 787819 & 11741681 & 40581 & 1516869 \\
\hline
\end{tabular}
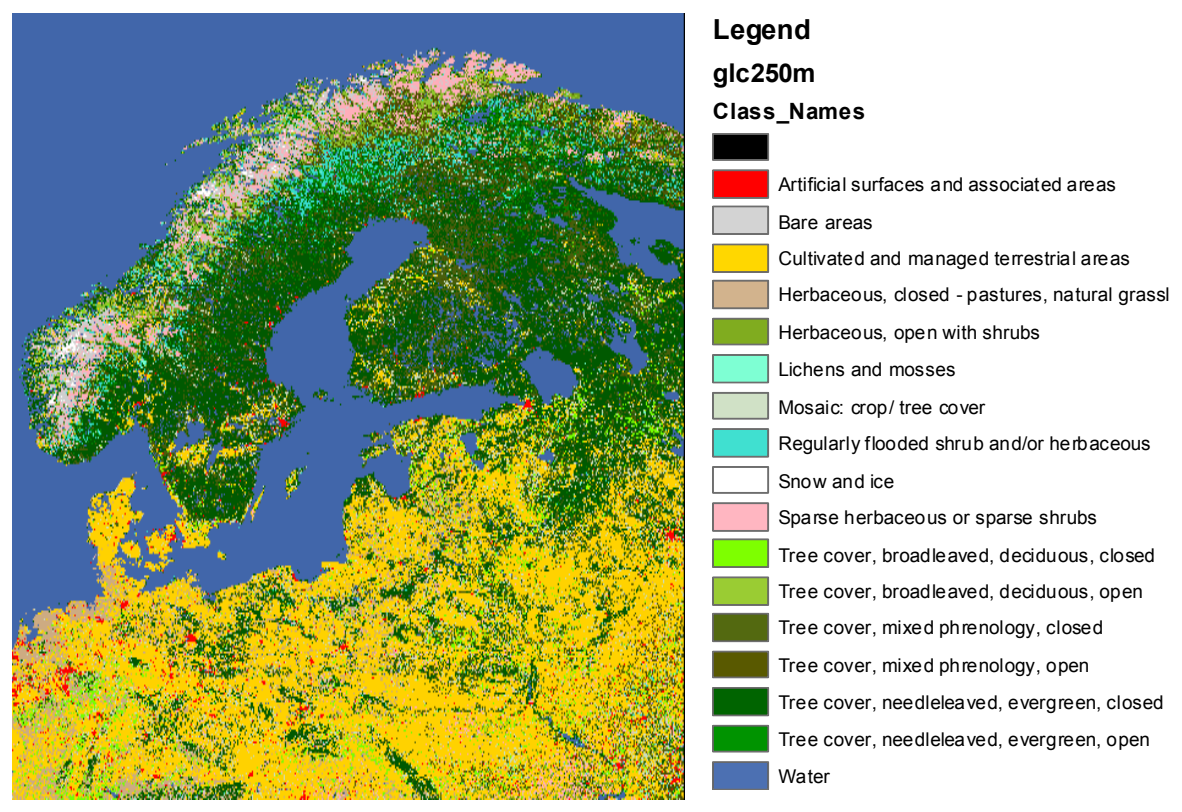

Fig. 2. Land classes for the Baltic Sea catchment. For the model simulations 10 classes were used, all herbaceous areas were aggregated to one class, tree classes were divided only into deciduous forest, mixed forest and coniferous forest, leaving us with the following classes; deciduous forest, coniferous forest, mixed forest, herbaceous areas, wetlands, cultivated areas, bare areas, water, snow and ice and artificial areas.

2005; Grant et al., 2006) will not lead to a significant lower nutrient inputs into the Baltic Sea, because Danish rivers contribute only with $8 \%$ to the riverine TN fluxes and $5 \%$ to the riverine TP fluxes, respectively (Table 2). Larger rivers that are more significant for the nutrient land sea fluxes to the Baltic, as for example the Odra and Vistula, drain cultivated landscapes where often less $\mathrm{N}$ and $\mathrm{P}$ was used in agriculture. In Poland, which stands for about $30-40 \%$ of the riverine TN and TP fluxes, respectively (Table 2), most agricultural land belonged to private landowners and, livestock was more evenly distributed over the country and inorganic fertilizer use was low during the last 50 years, i.e., between 30$80 \mathrm{~kg} \mathrm{Nha}^{-1} \mathrm{yr}^{-1}$ and $10-50 \mathrm{~kg} \mathrm{Pha}^{-1} \mathrm{yr}^{-1}$ (Sapek, 1997; Eriksson et al., 2007). This was about half the amount used in Denmark or Germany (FAO, 2005). Note that in Fig. 4a total amount of fertilizers $(\mathrm{N}, \mathrm{P}, \mathrm{K})$ is given as an overview over the general trend; $\mathrm{N}$ and $\mathrm{P}$ fertilizer were used much less in Poland, the Baltic States and Russia compared to Denmark, Germany, Sweden and Finland (Löfgren et al., 1999). However, for the rivers Vistula and Oder no decrease in river loads has been reported until 1998 (Witek et al., 2003; Eriksson et al., 2007), i.e., almost ten years after the drop in fertilizer use. This lack of a response pattern might be related to leakage thresholds (Oenema et al., 1998), i.e., that agricultural soils start to leak significant more amounts of nutrient when nutrient surpluses become higher than a certain amount agricultural soils can buffer due to storage and denitrification. In addition, inertia of the watershed may be of relevance, since groundwater residence times may last some decades in the major watersheds. However, as will be evaluated below 
Table 2. Load of nutrients by country via rivers and coastal points sources, averaged for 1997-2003, according to data reported to HELCOM.

\begin{tabular}{lcccc}
\hline Country & TN load (ton $\left.\mathrm{yr}^{-1}\right)$ & $\%$ & $\mathrm{TP}$ load $\left(\right.$ ton $\left.\mathrm{yr}^{-1}\right)$ & $\%$ \\
\hline Denmark & 57501 & $8 \%$ & 1795 & $5 \%$ \\
Estonia & 30870 & $4 \%$ & 1261 & $4 \%$ \\
Finland & 71110 & $10 \%$ & 3348 & $9 \%$ \\
Germany & 20848 & $3 \%$ & 533 & $1 \%$ \\
Lithuania & 48872 & $7 \%$ & 2534 & $7 \%$ \\
Latvia & 77051 & $10 \%$ & 2184 & $6 \%$ \\
Russia & 89386 & $12 \%$ & 6569 & $18 \%$ \\
Poland & 215350 & $29 \%$ & 13717 & $38 \%$ \\
Sweden & 125726 & $17 \%$ & 4003 & $11 \%$ \\
\hline SUM & 736714 & $100 \%$ & 35944 & $100 \%$ \\
\hline
\end{tabular}

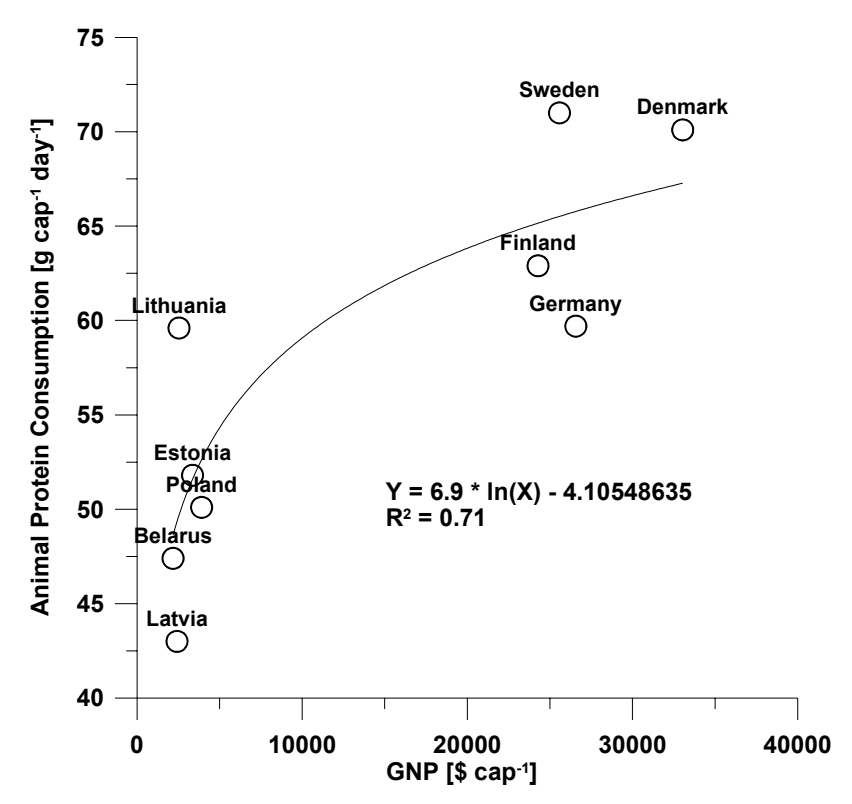

Fig. 3. Relationship between the gross national productivity per capita (GNP) and the animal protein consumption per capita for riparian Baltic Sea countries (Data from World Bank \& FAO).

in more detail, a decrease in $\mathrm{N}$ and $\mathrm{P}$ fertilizer use appears not very likely in those countries with transitional economies since a prospective growth in economy as indicated by the gross national product per capita is directly related to the consumption of animal proteins (Fig. 3) and this translates directly to the application of nutrients in the agricultural sector (Nixon, 1995).

A much more promising strategy to reduce riverine nutrient loads from transitional countries might be to connect more people to MWWTPs (Municipal Waste Water Treatment Plants) (Eriksson et al., 2007). MWWTPs with tertiary treatment were built for example in the 1990s in Poland and the percentage of the population connected to urban
Table 3. Levels of sewage treatment by country in 2004 .

\begin{tabular}{lccc}
\hline Country & $\begin{array}{c}\text { Primary } \\
\text { wwt } \%\end{array}$ & $\begin{array}{c}\text { Secondary } \\
\text { wwt } \%\end{array}$ & $\begin{array}{c}\text { Tertiary } \\
\text { wwt } \%\end{array}$ \\
\hline Belarus & 0 & 50 & 0 \\
Czech Republic & 0 & 61 & 0 \\
Denmark & 2 & 5.2 & 81.4 \\
Estonia & 2.2 & 34.4 & 33.6 \\
Finland & 0 & 0 & 80 \\
Germany & 0 & 9 & 85 \\
Lthuania & 33 & 6 & 18 \\
Latvia & 1.79 & 35.08 & 33.07 \\
Norway & 0 & 5.8 & 85.8 \\
Poland & 2.2 & 23.3 & 33.5 \\
Russia & 0 & 50 & 0 \\
Sweden & 0 & 5.8 & 85.8 \\
\hline
\end{tabular}

MWWTP increase gradually from $4 \%$ in 1995 to $34 \%$ in 2004 (Table 3). However, as indicated in Table 3 there is still an enormous potential to connect people to modern sewage cleaning in the transitional countries. Although the emissions from animals that contribute significantly to the diffusive sources are several fold higher than human emissions (Table 4), improved cleaning of these point sources is still a huge potential for the reduction in river loads, since point sources are emitted directly into stream waters whereas emissions from manure are significantly retained in the soils ( $>80 \%$ ) before entering the aquatic conduit (Johnes et al., 1996).

To summarize the current situation on riverine TN and TP fluxes to the Baltic Sea, there are (were) hot spots of diffuse sources as for example the Estonian or Danish agriculture where indeed reductions in nutrient loads have been observed as a result of a reduction in nutrient surpluses in agricultural areas. These hot spots are probably less significant for the nutrient mass fluxes to the Baltic Sea. A probably 
Table 4. Annual emissions of nutrients from cattle (milk cows, other cattle), pigs (slaughter pigs and sows) and humans (kg unit ${ }^{-1} \mathrm{year}^{-1}$ ) by country.

\begin{tabular}{lcccccccccc}
\hline Country & \multicolumn{2}{c}{ Milk cows } & \multicolumn{2}{c}{ Other cattle } & \multicolumn{2}{c}{ Slaughter pigs } & \multicolumn{2}{c}{ Sows } & \multicolumn{3}{c}{ Humans } \\
\hline & $\mathrm{N}$ & $\mathrm{P}$ & $\mathrm{N}$ & $\mathrm{P}$ & $\mathrm{N}$ & $\mathrm{P}$ & $\mathrm{N}$ & $\mathrm{P}$ & $\mathrm{N}$ & $\mathrm{P}$ \\
\hline Belarus & 47.4 & 9.8 & 34.0 & 4.5 & 8.8 & 3.6 & 22.0 & 9.0 & 3.9 & 1.1 \\
Czech Republic & 63.0 & 11.8 & 34.0 & 4.5 & 8.8 & 3.6 & 22.0 & 9.0 & 3.9 & 1.1 \\
Denmark & 74.2 & 13.3 & 34.0 & 4.5 & 8.8 & 3.6 & 22.0 & 9.0 & 3.9 & 1.1 \\
Estonia & 94.3 & 15.9 & 34.0 & 4.5 & 8.8 & 3.6 & 22.0 & 9.0 & 3.9 & 1.1 \\
Finland & 84.8 & 14.6 & 34.0 & 4.5 & 8.8 & 3.6 & 22.0 & 9.0 & 3.9 & 1.1 \\
Germany & 96.1 & 16.1 & 34.0 & 4.5 & 8.8 & 3.6 & 22.0 & 9.0 & 3.9 & 1.1 \\
Lithuania & 63.5 & 11.9 & 34.0 & 4.5 & 8.8 & 3.6 & 22.0 & 9.0 & 3.9 & 1.1 \\
Latvia & 62.2 & 11.7 & 34.0 & 4.5 & 8.8 & 3.6 & 22.0 & 9.0 & 3.9 & 1.1 \\
Norway & 101.6 & 16.8 & 34.0 & 4.5 & 8.8 & 3.6 & 22.0 & 9.0 & 3.9 & 1.1 \\
Poland & 63.0 & 11.8 & 34.0 & 4.5 & 8.8 & 3.6 & 22.0 & 9.0 & 3.9 & 1.1 \\
Russia & 47.4 & 9.8 & 34.0 & 4.5 & 8.8 & 3.6 & 22.0 & 9.0 & 3.9 & 1.1 \\
Sweden & 101.6 & 16.8 & 34.0 & 4.5 & 8.8 & 3.6 & 22.0 & 9.0 & 3.9 & 1.1 \\
\hline
\end{tabular}

much larger part of the agriculture in transitional countries around the Baltic is more like Polish agriculture, still with relatively low N and P use (Sapek, 1997) and consequently low nutrient leakage to the environment. In many transitional countries bordering the Baltic Sea there is a huge potential to reduce nutrient loads by connecting more people to MWWTPs with tertiary cleaning. However, this decrease in nutrient load might be compensated by a change in life styles and application of more TN and TP in the agriculture. To estimate the potential effects of these drivers on riverine TN and TP fluxes to the Baltic Sea, we simulated the following three scenarios: i) better sewage treatment in transitional countries, ii) the application of P-free detergents in all Baltic Sea riparian countries and iii) a more intensive livestock in transitional countries caused by an increase in animal protein consumption. Note that these scenarios are no predictions and their objective is rather to indicate the major direction of change in nutrient loads to the Baltic Sea that may probably develop as a consequence of changes in lifestyles and certain management strategies. However, despite all uncertainties involved that are mainly caused by the simplicity of the hydrological approach (see below) and the disrespect of detailed agricultural practices and future climate changes, these scenarios may well indicate the orders of magnitude of change, i.e., these scenario analyses are a scaling exercise to elucidate whether future drivers may alter land-sea nutrient fluxes by some few percent or by more significant amounts.

The decision support system NEST (Johansson et al., 2007) has been developed to analyse the effect of different management actions of the Baltic Sea. It consists of a marine biogeochemical model of the entire Baltic Sea linked to a drainage basin model, which handles the various nutrient emissions from land and describes the net export to the sea. The latter model was linked to an emission database, which allows the formulation of alternative scenarios for remedial actions. To date, such a model has been lacking on the Baltic Sea scale and a detailed description of the model, which is called CSIM model, is given in Mörth et al. (2007). CSIM, is a lumped hydrologic model (Fig. 6) based on the generalized watershed loading function model (Haith et al., 1987) originally developed to simulate streamflow, sediment, and nutrient fluxes from mixed-use watersheds in the United States. The model was applied to the entire Baltic Sea drainage basin divided into separate watersheds (Fig. 1). This division was necessary to handle this complex ecosystem, but it required a consistent handling of emission data from more than 100 watersheds draining into the Baltic Sea. TN and TP fluxes were described by means of the water flows through various landscape types of a watershed, including surface and ground water transports. Precipitation and evapotranspiration is applied to each land cover type in the Baltic Sea catchment and was estimated using the algorithms given in the original GWLF model (Haith et al., 1987). Water from each land cover type is then routed to streams both as direct surface runoff and indirectly, down through two subsurface layer compartments, as groundwater runoff; each of which contributes a component of stream baseflow. Thus, the stream flow consists of total surface runoff from individual land use classes in the watershed and groundwater contributions from two common groundwater compartments handling the discharge from the saturated zone. The uppermost of the two flow paths of groundwater discharge responds to precipitation relatively quickly while the lower path has a slow climate response, not substantially affecting the seasonal stream water discharge pattern.

The model operates with characteristic concentrations for the various landscape types of inorganic and total $\mathrm{N}$ and $\mathrm{P}($ dissolved inorganic nitrogen $=\mathrm{DIN}$; dissolved inorganic 

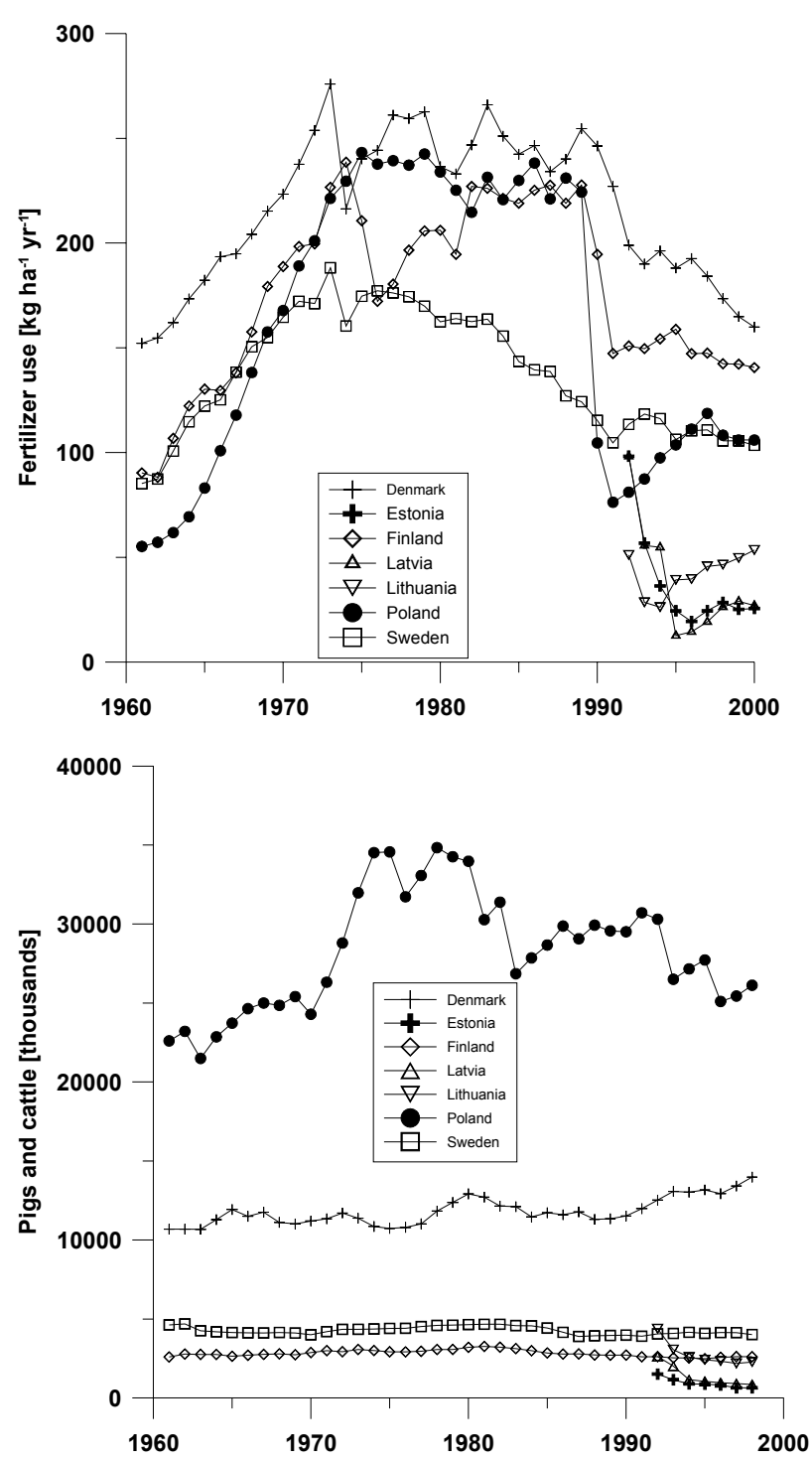

Fig. 4. Development of fertilizer use (a) and number of livestock (b) in riparian Baltic Sea countries.

phosphorus (DIP); total nitrogen (TN) and total phosphorus (TP)) in surface and ground waters. Atmospheric deposition is not simulated dynamically, but is addressed in the type concentrations of various landscape types in the Baltic Sea catchment that the model requires to estimate nutrient transport. Nitrogen and phosphorus loads in stream flow are calculated as the product of water discharge and the specified nutrient concentrations, with the addition of three types of sources, i.e., handling of manure as well as sewage in rural respectively urban areas. Sewage is calculated from the distribution of urban and rural population, the degree of connection to MWWTPs and the effectiveness of their waste treatment.

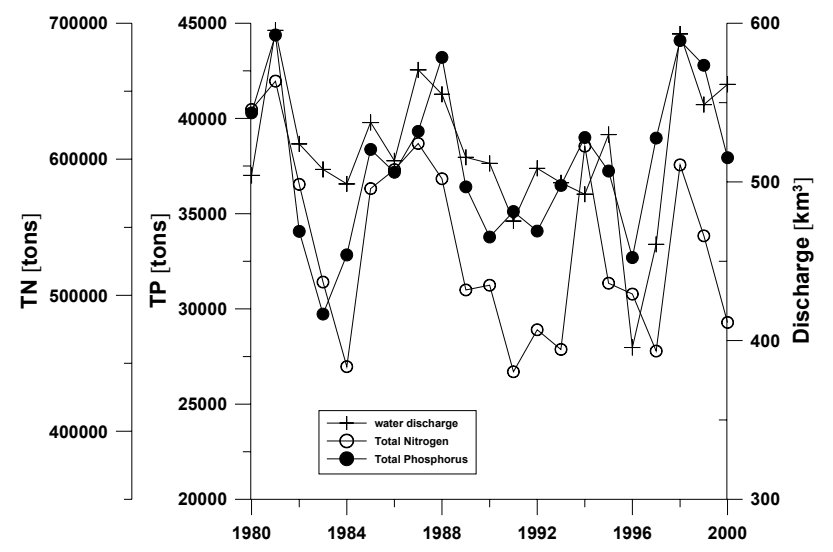

Fig. 5. Transport of total nitrogen (TN), total phosphorus (TP) and water discharge by major Baltic Sea rivers $(n=85)$ over time.

Since in-stream biological uptake is not described dynamically in the model, the in-stream retention was fitted during model calibration by comparing the net emissions into the streamwaters (that is diffuse inputs after soil retention and point sources after treatment) and the observed nutrient loads at the river mouth over the calibration period. The mean in-stream retention for all simulated rivers was about $15 \%$ for TN and $19 \%$ for TP. In other words, the estimated loads to rivers were about $15-20 \%$ higher on average than the measured loads at the river mouth, which is somewhat lower compared to estimates made by various model approaches complied in the latest PLC $(\sim 30 \%$ for both TN and TP; HELCOM, 2004) and by estimates in US river systems (Seitzinger et al., 2002).

The CSIM model simulates water (streamflow) and nutrient fluxes (TN, TP) fairly well (Mörth et al., 2007). The interannual variability of water and nutrient fluxes were reasonably well described for the 105 watersheds where, across all watersheds and years of the validation period (1991-1995; monthly data for all variables and watersheds), 91\%, 92\% and $95 \%$ of the overall variability in streamflow, $\mathrm{TN}$ and $\mathrm{TP}$, respectively, could be described by the model. CSIM was also able to describe the annual streamflow and TN loads fairly well, i.e., these fluxes were overestimated with $4 \%$ and 5\%, respectively; TP loads were overestimated by $25 \%$. Even the seasonal fluctuations of streamflow that might be crucial for TN and especially TP fluxes could be simulated reasonably well with CSIM (Fig. 7). The flow patterns of the Råneälven, an unperturbed boreal river in Northern Sweden draining a watersheds area of $4137 \mathrm{~km}^{2}$, were well described and the spring peak flow in May-June was correctly indicated by the model $\left(R^{2}\right.$ of 0.72 between measured and simulated values); similarly the flow patterns in the eutrophic Oder River, draining a watersheds area of $117589 \mathrm{~km}^{2}$, were also well described and the spring peak flow in April-May was correctly indicated by the model $\left(R^{2}\right.$ of 0.44 between measured and simulated values). 


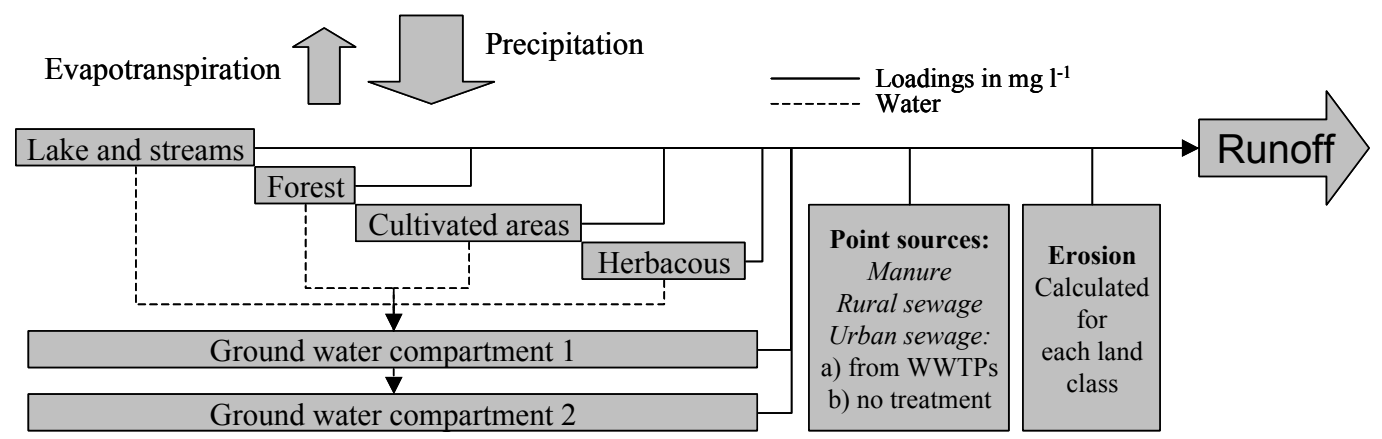

Fig. 6. Model architecture for CSIM. Precipitation and evapotranspiration were applied on each of the various land covers. Water from each land cover type was routed both directly to stream flow and down to the soil water compartment. From the soil water compartment water was routed to stream flow and to the groundwater compartment, and from there on to the stream. Four types of point sources were considered. Sewage nutrient load is calculated from the distribution of the urban and rural population, and the degree of connection to WWTP and the effectiveness of the treatment (primary, secondary and tertiary).

In short, the model simulates the annual water balance for all 105 major Baltic watersheds as well as their nutrient loads from natural and anthropogenic sources. The effect of better cleaning of point sources which were estimated in scenario i) were addressed using information on the proportion of the watershed population connected to sewage treatment and information on the degree of treatment, i.e. primary, secondary or tertiary treatment (Table 3). To simulate the effect of using P-free detergents (scenario ii) we used the information on the distribution of urban vs. rural population in a given watershed and applied a fixed amount of emission reductions per capita. The effect of using P-free detergence by the urban population is generally higher, since soil retention of rural emissions (Johnes et al., 1996) was assumed higher than $\mathrm{P}$ retention in sewage treatment (see below). The effect of diffusive emissions influenced by man that were estimated in scenario iii) was parameterized as increased nutrient inputs from manure due to higher livestock that enter the streamwater after significant soil retention ( $83 \%$ for $\mathrm{TN}$ and $97 \%$ for TP; (Johnes et al., 1996). This means that manure is simply added as an additional load to streamwater without changing groundwater type concentrations of cultivated land.

\subsubsection{Scenario $i$}

The first scenario runs on the effects of improved sewage treatment (Wulff et al., 2007) were based on averaged national data on people connected to sewage systems for the period 1996-2000 retrieved from official statistics from EUROSTAT (http://europa.eu.int/comm/eurostat/) (Mörth et al., 2007). Efforts by the HELCOM member countries made it possible to update this information with more recent and accurate data. In the current analysis we have updated data on levels of sewage treatments until 2004 (Table 3). Primary treatment was assumed to reduce the $\mathrm{N}$ and $\mathrm{P}$ loads by $19 \%$ and $15 \%$, respectively, while secondary treatment reductions were assumed with $37.5 \%$ for $\mathrm{N}$ and $35 \%$ for P. Finally, ter-

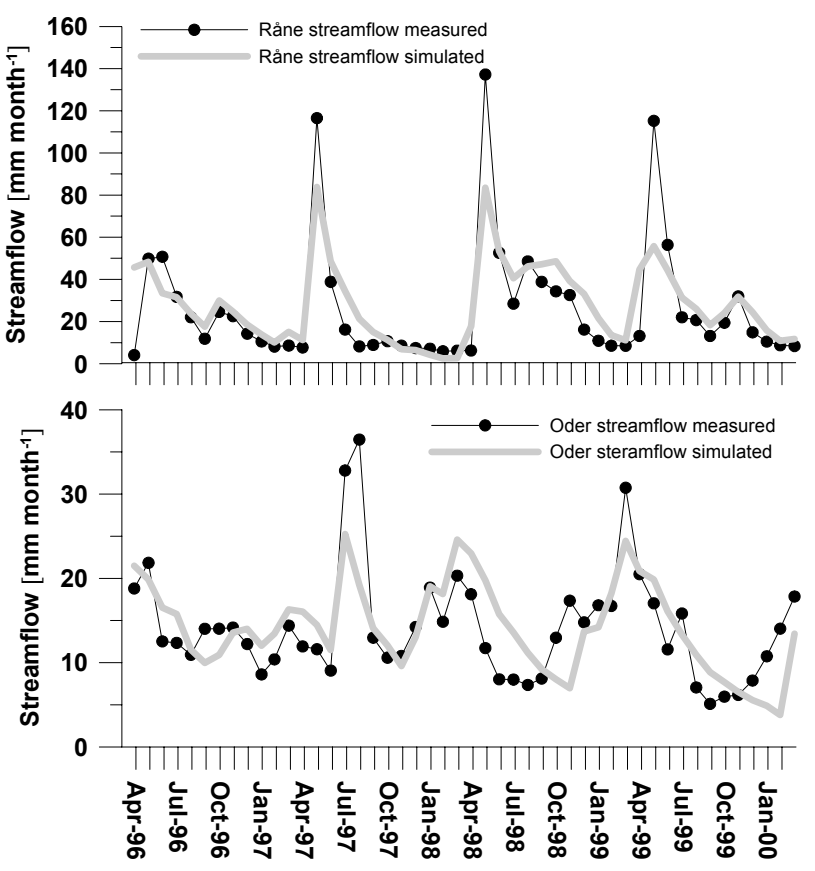

Fig. 7. Seasonal simulations and measured monthly streamflow for (a) the unperturbed high altitude Råne watershed and (b) the cultivated watershed of the Oder.

tiary treatment was assumed to remove $80 \%$ and $90 \%$ of $\mathrm{N}$ and $\mathrm{P}$, respectively (values are taken from EUROSTAT). We have also through informal discussions with Russian and Belarusian scientists updated these data, assuming that $50 \%$ of the populations in the Baltic Sea drainage basins of these countries are now connected to secondary sewage treatment. In our scenario calculations, we have assumed that no further improvement will occur in the Nordic countries or Germany, compared to 2004. The other countries will have an improvement in sewage treatment, corresponding to $80 \%$ and $90 \%$ of 
Table 5. Load reductions/increase of nutrients by country anticipated under the various scenarios $i-i i i$.

\begin{tabular}{|c|c|c|c|c|c|c|c|c|c|c|}
\hline \multirow[b]{2}{*}{ Country } & \multicolumn{4}{|c|}{ Scenario $i$} & \multicolumn{2}{|l|}{ Scenario $i i$} & \multicolumn{4}{|c|}{ Scenario iii } \\
\hline & $\begin{array}{l}\text { TN reduction } \\
\left(\text { ton } \mathrm{yr}^{-1}\right)\end{array}$ & $\%$ & $\begin{array}{l}\text { TP reduction } \\
\left(\text { ton } \mathrm{yr}^{-1}\right)\end{array}$ & $\%$ & $\begin{array}{l}\text { TP reduction tons } \\
\quad\left(\text { ton } \mathrm{yr}^{-1}\right)\end{array}$ & $\%$ & $\begin{array}{l}\text { TN increase } \\
\left(\text { ton } \mathrm{yr}^{-1}\right)\end{array}$ & $\%$ & 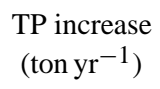 & $\%$ \\
\hline Belarus & -5574 & $16 \%$ & -1977 & $16 \%$ & -401 & $12 \%$ & 58684 & $17 \%$ & 2449 & $15 \%$ \\
\hline Czech rep & -1293 & $4 \%$ & -391 & $3 \%$ & -80 & $2 \%$ & 2839 & $1 \%$ & 117 & $1 \%$ \\
\hline Denmark & & & & & -104 & $3 \%$ & - & - & - & - \\
\hline Estonia & -604 & $0 \%$ & -133 & $1 \%$ & -33 & $1 \%$ & 16329 & $5 \%$ & 925 & $6 \%$ \\
\hline Finland & - & - & - & - & -160 & $5 \%$ & 4105 & $1 \%$ & 318 & $2 \%$ \\
\hline Germany & - & - & - & - & - & - & 5199 & $2 \%$ & 465 & $3 \%$ \\
\hline Lithuania & -1151 & $3 \%$ & -615 & $5 \%$ & -202 & $6 \%$ & 38825 & $11 \%$ & 2504 & $16 \%$ \\
\hline Latvia & -203 & $1 \%$ & -187 & $2 \%$ & -55 & $2 \%$ & 21278 & $6 \%$ & 1339 & $8 \%$ \\
\hline Norway & - & - & - & - & -3 & $0 \%$ & 255 & $0 \%$ & 21 & $0 \%$ \\
\hline Russia & -12138 & $36 \%$ & -3829 & $31 \%$ & -769 & $24 \%$ & 32406 & $10 \%$ & 1366 & $8 \%$ \\
\hline Poland & -13338 & $39 \%$ & -5292 & $43 \%$ & -1326 & $41 \%$ & 149756 & $44 \%$ & 5736 & $36 \%$ \\
\hline Sweden & - & - & - & - & -106 & $3 \%$ & 11182 & $3 \%$ & 836 & $5 \%$ \\
\hline SUM & -34300 & $100 \%$ & -12424 & $100 \%$ & -3238 & $100 \%$ & 340859 & $100 \%$ & 16076 & $100 \%$ \\
\hline
\end{tabular}

$\mathrm{N}$ and $\mathrm{P}$ removal, respectively, i.e. this scenario refers to the best available technique. The drainage basin model (Mörth et al., 2007) yields the following 5-year mean load reductions to the different basins from each country into the corresponding drainage basins. The overall TN load (Table 2) according to this scenario will be reduced by $5 \%$ (minus 34000 tons $\mathrm{yr}^{-1}$; Table 5) and the TP loads by $35 \%$ (minus 12000 tons $\mathrm{yr}^{-1}$; Table 5). The higher relative effect (\%) of improved sewage treatment on TP fluxes compared to TN fluxes to the Baltic Sea can be explained by the dominance of diffusive sources for the TN fluxes that constitute roughly $60 \%$ of the total emissions (Mörth et al., 2007; HELCOM, 2004) and a more drastic decrease in TP fluxes (minus 90\%) from point sources compared to TN fluxes (minus $80 \%$ ) using tertiary cleaning. No reductions occur in the Bothnian Bay or Bothnian Sea, the Danish Sounds or Kattegat since direct loads to these basins originate only from the Nordic countries and Germany (Danish Sounds). The largest reduction of both TP and TN load with improved sewage treatment is from Poland (43\%; $39 \%)$, followed by Russia $(31 \% ; 36 \%)$ and Belarus $(16 \%$; $16 \%$ ) (Table 5). The effect of improved sewage treatment can be observed immediately as has been shown for $\mathrm{N}$ in the Oder and Vistula watersheds (Eriksson et al., 2007), since sewage treatment has been improved in Poland substantially within the last ten years. Thus, a possible time frame to reach scenario $i$ could be several years only.

\subsubsection{Scenario $i i$}

P contributions from the use of phosphates in detergents are largely dependent on use patterns, marketing conditions and the adoption of specific conditions on the use of phosphates in detergents either through regulatory or voluntary agreements. It is likely that these numbers will vary between countries. The annual contribution from detergents range from 0.13 to $0.22 \mathrm{~kg}$ per person (Zessner et al., 2005) and we have chosen to run the scenario where $\mathrm{P}$ emissions are reduced by $0.2 \mathrm{~kg}$ per person and year. This number has been obtained from a study in the Danube watershed, since no detailed information about the Baltic Sea riparian countries could be retrieved. However, the Danube watershed consists also of a similar mixture of western type economies and countries with economies in transition. The total $\mathrm{P}$ load reductions to the Baltic Sea amount to about 3200 tons $\mathrm{P} \mathrm{yr}^{-1}$ and the highest effects will be achieved in Poland (minus 1300 tons $\mathrm{P} \mathrm{yr}^{-1}$; Table 5) that has the largest population. Since $\mathrm{P}$ free detergents can be introduced rather quickly in all riparian countries and will decrease the emissions to and from MWWTPs immediately, the time frame to fulfil scenario ii could be several years only.

\subsubsection{Scenario iii}

In the last scenario we estimated the effects of a denser livestock in those counties recently assessed to the EU. During the last century, agricultural practices have change dramatically. New technologies, crops, animal breeding and, particularly, the introduction of artificial fertilizers, have increased productivity enormously. At the same time, consumer preferences have changed dramatically towards a large proportion of meat in human consumption. These changes have been most pronounced in the western countries (Fig. 3) but similar changes are now occurring in the new EU member states, as well as in Russia and Belarus. Higher living standards and EU agricultural subsidies are driving this development. In this scenario we have assumed that all countries around the Baltic Sea will develop their agriculture to the same state as in Denmark, the country that is leading in terms of agricul- 
Table 6. Livestock density in the Baltic Sea catchment by country.

\begin{tabular}{lcccccc}
\hline Country & Catchment Area ha & Cultivated are ha & Pigs & Pigs/ha & Cattle & Cattle/ha \\
\hline Belarus & 8918570 & 5134108 & 1283615 & 0.25 & 1034096 & 0.20 \\
Czech Rep & 954174 & 612990 & 541260 & 0.88 & 208048 & 0.34 \\
Denmark & 2696949 & 2191004 & 7022347 & 3.21 & 1202578 & 0.55 \\
Estonia & 4491244 & 1984645 & 262188 & 0.13 & 274278 & 0.14 \\
Finland & 30273828 & 2689822 & 1122538 & 0.42 & 933285 & 0.35 \\
Germany & 2624100 & 1867206 & 1832271 & 0.98 & 1016576 & 0.54 \\
Latvia & 6478096 & 3277510 & 500635 & 0.15 & 540289 & 0.16 \\
Lithuania & 6469354 & 4012765 & 832187 & 0.21 & 832195 & 0.21 \\
Norway & 1394112 & 122225 & 71841 & 0.59 & 56765 & 0.46 \\
Poland & 32207281 & 20677731 & 17167399 & 0.83 & 6615023 & 0.32 \\
Russia & 33005131 & 8261300 & 898546 & 0.11 & 945341 & 0.11 \\
Sweden & 43927634 & 3625003 & 2125061 & 0.59 & 1676599 & 0.46 \\
\hline Grand Total & 173440472 & 54456309 & 33659887 & 0.62 & 15335072 & 0.28 \\
\hline
\end{tabular}

tural development. More specifically, we assume that each country will have the same number of milk cow and other cattle, sows and slaughter pigs per agricultural areas as in Denmark (Table 6). This would imply a massive increase in livestock densities in the transitional countries as expressed in animals per hectare, i.e., for pigs an increase between a factor of 4-30 and for cattle between a factor of 1.6-5 (Table 6). Moreover, the productivity, in term of meat and milk per animal will increase to Danish levels, which also means that nutrient excretion per unit animal will increase (Table 4). In this "pessimistic" scenario we also assumed that sewage treatment will remain at the 2004 levels and no further restriction in the use of $\mathrm{P}$ in detergents will be implemented. The effect of this massive life stock increase could result in an increase of the order of 16000 tons TP and 340000 tons TN (Table 5) which corresponds to roughly a 50\% increase in total river loads (Table 2).

As mentioned already, this scenario tries to scale a possible change in loads due to increased livestock, rather than to give exact numbers. Since uncertainties to address future scenarios on diffuse sources such as from agriculture are much more difficult to handle compared to future estimates on point source emissions, scenario iii has to be treated with caution. The exact increase in nutrient loads will be a function of agricultural practices, such as farm sizes, the storage and handling of manure or whether livestock is held in modern stables or outdoor as well which kind of livestock (slaughter cattle or milk cows, slaughter pigs or sows) at which production level will be used. However, it is obvious that those rivers draining cultivated land with high livestock and meat production as in the Baltic Sates (Löfgren et al., 2000) were the only rivers within the Baltic Sea catchment that had similar elevated $\mathrm{N}$ and $\mathrm{P}$ concentrations as found in western Europe and these rivers showed an immediate response in nutrient loads after livestock reductions (Iital et al.,
2005). Thus, a change in livestock is apparently a driver that can be observed in river chemistry rather quickly. Hence, a rather fast switch back to former nutrient loadings appears reasonable when livestock densities will rise again and these numbers may even exceed former values, since western type agricultural practices as now introduced everywhere in the transitional countries are even more intense in $\mathrm{N}$ and $\mathrm{P}$ use compared to the conditions prior to the political changes in 1989. In contrast, changes in climate might decrease water runoff to the Baltic in the southeastern catchments of the Baltic Sea with some 15\% (Graham, 2004), which may significantly influence nutrient fluxes from this part of the Baltic Sea catchment, since N and P loads to the Baltic Sea are highly correlated with the water discharge (Fig. 5). However, CSIM does not parameterize changes in water pathways that may probably come along with warmer temperatures and changes in groundwater tables, and these drivers are beyond the scope of this scenario analysis. In the same vein, the time frame of such a scenario is highly unknown, but since manure emissions are diffuse emissions, an increase in manure can only be observed on longer time scales, i.e. decades, compared to the effects addressed under scenario $i$ and $i$.

\subsection{Past and possible future changes in Si fluxes}

From several studies in boreal and sub arctic Swedish watersheds we hypothesized that perturbed surface watergroundwater interactions as a consequence of the hydrological alterations in the rivers of the northern watershed of the Baltic lead to changes in weathering conditions. Thus, less weathering may be the major reason for the reduced DSi loads observed in these oligothrophic boreal rivers (Humborg et al., 2000; Humborg et al., 2002; Humborg et al., 2006b). Particle trapping of biogenic silica (BSi) - that is mainly diatom shells - behind dams is the main reason for the 
Table 7. DSi annual inputs and potential missing DSi loads divided by Baltic Sea subbasin $(\mathrm{BB}=\mathrm{Bothnian} \mathrm{Bay}, \mathrm{BS}=\mathrm{Bothnian}$ Sea, GF $=$ Gulf of Finland, GR = Gulf of Riga, BP = Baltic proper).

\begin{tabular}{lcccccc}
\hline Sub-basin & $\begin{array}{c}\text { Area } \\
\left(\mathrm{km}^{2}\right)\end{array}$ & $\begin{array}{c}\text { Runoff } \\
\left(10^{6} \mathrm{~m}^{3} \mathrm{yr}^{-1}\right)\end{array}$ & $\begin{array}{c}\text { Spec. Runoff } \\
\left(1 \mathrm{~m}^{-2} \mathrm{yr}-1\right)\end{array}$ & $\begin{array}{c}\mathrm{DSi} \\
\left(\mathrm{ton} \mathrm{r}^{-1}\right)\end{array}$ & $\begin{array}{c}\mathrm{DSi} \text { yield } \\
\left(\mathrm{kg} \mathrm{km}^{-2} \mathrm{yr}^{-1}\right)\end{array}$ & $\begin{array}{c}\text { Missing DSi } \\
\left({\left.\text { ton } \mathrm{yr}^{-1}\right)}^{-1}\right.\end{array}$ \\
\hline BB & 235499 & 97064 & 412 & 220855 & 938 & 56079 \\
BS & 197061 & 86543 & 439 & 151823 & 770 & 98786 \\
GF & 384853 & 105779 & 275 & 55823 & 145 & 105262 \\
GR & 122116 & 29609 & 242 & 52820 & 433 & 19458 \\
BP & 488394 & 85320 & 175 & 230030 & 471 & 114197 \\
Unmonitored & 196604 & 69218 & & 143670 & & 26671 \\
& 1624527 & 473533 & & 855021 & & 420453 \\
\hline
\end{tabular}

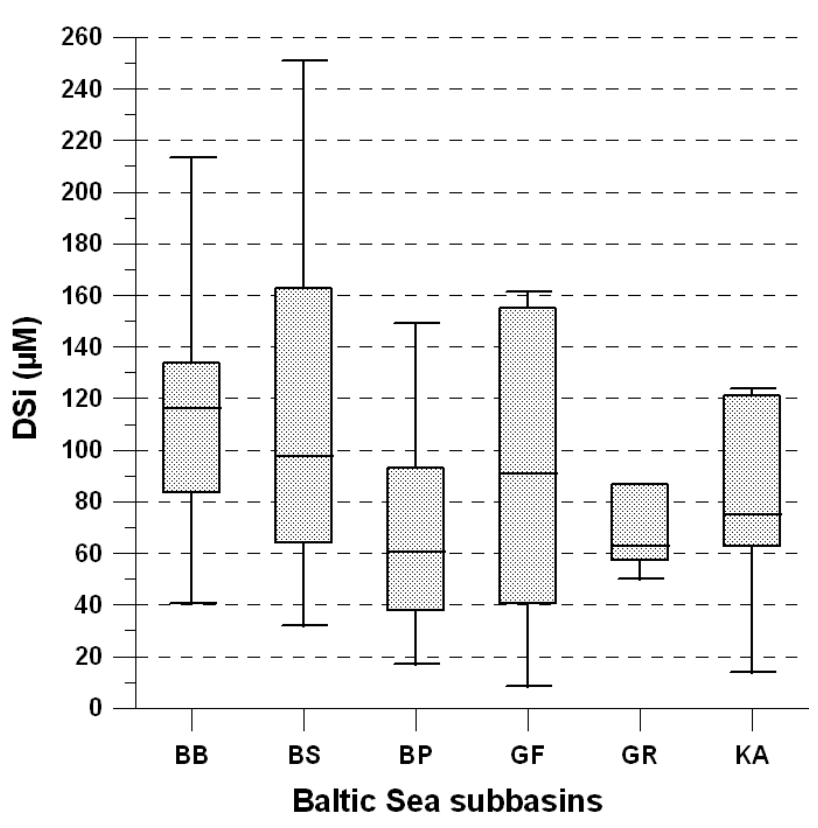

Fig. 8. DSi concentrations of major rivers classified by the major basins of the Baltic Sea they run to $(\mathrm{BB}=$ Bothnian Bay, $\mathrm{BS}=$ Bothnian Sea, GF $=$ Gulf of Finland, GR $=$ Gulf of Riga, BP = Baltic proper, $\mathrm{KA}=$ Kattegat).

reduced Si loads in the cultivated watersheds of the southern catchment of the Baltic (Humborg et al., 2006b). Thus, the main processes behind the reduced DSi loads to the Baltic Sea were described, but an overall estimate on the effects of both processes for the reduction of the overall Si load to the Baltic Sea is still missing.

DSi yields of the major rivers were about twice as high in the northern boreal and sub arctic part of the Baltic catchments compared to the agriculture dominated and eutrophied southeastern catchments (Table 7). Expressed in concentrations the rivers of the BB, BS, GF, GR, BP and KA showed median concentrations of $118,100,91,70,60$ and $79 \mu \mathrm{M}$, respectively (Fig. 8), all far below the world average DSi concentration of $156 \mu \mathrm{M}$ (Treguer et al., 1995). In fact, they show the opposite patterns to what is expected, since it is well known that chemical weathering rates of silicate minerals are related to temperature (Meybeck, 1979; Berner et al., 1995). Many watersheds of the northern part are affected mainly by damming and the area weighted sub catchment yields are much less than observed in unperturbed rivers of the area. The extreme low DSi yield of the Gulf of Finland catchment is caused by the disproportional large River Neva draining the eutrophied Lake Ladoga (Rukhovets et al., 2003) that probably sequesters DSi efficiently. Low yields were also observed for those rivers of the eutrophied catchments of the Gulf of Riga and the Baltic proper that have high percentages in lake area and/or are dammed. The effects of BSi particle trapping occurring in the southeastern rivers together with the massive hydrological alterations in the northern rivers have lead to a DSi load reduction by approximately one third from 1.28 million tons in the early 1900s to about 0.85 million tons today (Table 7 ).

These estimates are based on monthly measurements (1980-2000) on DSi loads from 83 major rivers (Fig. 1) running into the Baltic Sea that have been used to calculate DSi yields ( $\mathrm{kg} \mathrm{DSi} \mathrm{km}^{2} \mathrm{yr}^{-1}$ ) to the various Baltic Sea basins. To calculate unperturbed potential DSi yields for all these watersheds we assumed pristine yields for each geological subregion of the Baltic catchment: Both Sweden and Finland have acid volcanic and plutonic acid rocks and we chose the Rivers Kalixälven $\left(1261 \mathrm{~kg} \mathrm{~km}^{2} \mathrm{yr}^{-1}\right)$ for Swedish rivers and Kiiminkijokki (1266 kg km${ }^{2} \mathrm{yr}^{-} 1$ ) for Finnish rivers as unperturbed backgrounds. Sedimentary rocks dominate the southern and eastern part of the Baltic Sea catchment. We calculated a potential yield of $704 \mathrm{~kg} \mathrm{~km}^{2} \mathrm{yr}^{-1}$ for the southern part (non to semi consolidated sedimentary rocks) based on bimonthly observations (2003-2004) of DSi and biogenic silica (BSi). BSi is a substantial part of the total Si load (median of about $50 \mu \mathrm{M}$; Humborg et al., 2006) in the undammed Oder River and was included in the calculations of Si yields. For the eastern part (consolidated sedimentary rocks), we chose the River Gauja and a potential yield of 
$668 \mathrm{~kg} \mathrm{~km}^{2} \mathrm{yr}^{-1}$ was estimated based on actual DSi observations and assumed contribution of BSi as in the similar eutrophied River Oder. Thereafter, we normalised each watershed yield against the specific runoff and temperature differences to the pristine yield of the geologic area:

$\mathrm{DSi}_{\text {pot }}=\mathrm{DSi}_{\text {norm }} \times \frac{\text { runoff }_{\text {obs }}}{\text { runoff }_{\text {norm }}} \times 1.08^{\left(t_{\text {obs }}-t_{\text {norm }}\right)}$

where $\mathrm{DSi}_{\text {pot }}$ is the potential unperturbed DSi yield $\left[\mathrm{kg} \mathrm{km}^{-2} \mathrm{yr}^{-1}\right]$ of the watershed, $\mathrm{DSi}_{\text {norm }}$ is the pristine yield of the geologic area, runoff ${ }_{\text {obs }}$, runoff norm $_{\text {and }} t_{\mathrm{obs}}, t_{\text {norm }}$ are the specific runoff $\left[1 \mathrm{~m}^{-2} \mathrm{yr}^{-1}\right]$ and average annual temperature $\left[{ }^{\circ} \mathrm{C}\right]$ of the watershed and the pristine watershed, respectively. The temperature differences between the watersheds were multiplied by a factor 1.08 , taking into account an increase in weathering of about $8 \%$ per degree Celsius for plagioclase (Lasaga, 1998), a representative silicate mineral for the entire area. The catchments with eutrophied large lakes namely the Rivers Neva, Motalaström and Norrström we assumed a decrease in DSi loads by a factor 4 similar as has been observed in the Great Lakes (Schelske et al., 1983); a more conservative estimate than would have resulted from normalization. Finally, we subtracted the observed DSi yield (Table 7) from the potential unperturbed DSi yield of all watersheds to calculate the missing DSi loads (Table 7) to the Baltic Sea that were further aggregated to sub catchment scale.

Future perspectives on DSi fluxes are difficult to estimate in terms of quantitative estimates with the current information on future energy demands at hand, however, DSi loads to the Baltic Sea will probably continue to decrease, since many more dams might be erected due to an increasing demand of hydropower (Lehner et al., 2005) during the next decades. Highest effects of hydropower can be foreseen in Sweden and Finland that constitute the major part of the boreal catchment of the Bothnian Bay and Bothnian Sea, since the specific discharge is much higher compared to the cultivated part of the Baltic Sea catchment (Table 7) and water discharge is expected to increase due to higher rainfall with global warming (Graham, 2004). The status of low DSi loads from the southern part of the Baltic Sea might be conserved due to a similar eutrophication status of lakes and reservoirs, a further eutrophication as envisioned in the higher livestock scenario (see above) might however further decrease DSi loads to the Baltic Sea also from the cultivated watersheds. Thus, a further decrease in DSi river loads to the Baltic Sea may drive the decreasing DSi concentrations in the Baltic Sea (Humborg et al., 2006a) to concentrations where diatom growth becomes suboptimal (Egge et al., 1992).

2.3 Past and possible future changes in dissolved organic and inorganic $\mathrm{C}$ fluxes

It is estimated that about $455 \mathrm{Pg} \mathrm{C}$ is stored in northern peatlands, corresponding to about $30 \%$ of all soil C on Earth or to

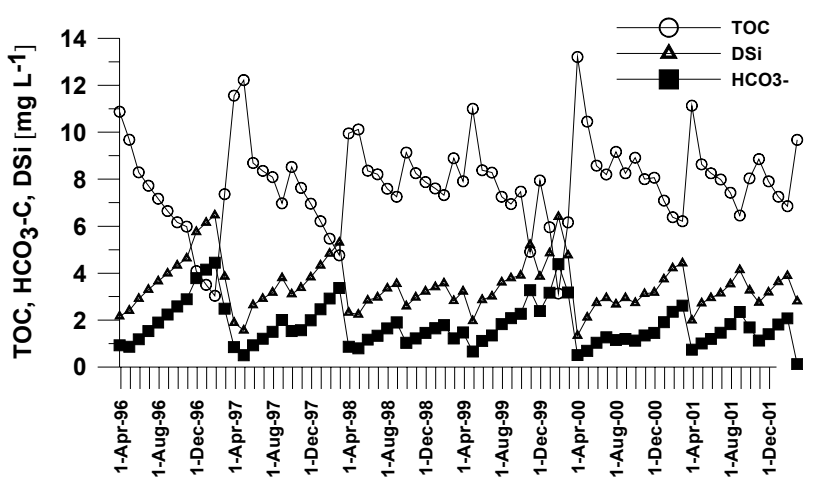

Fig. 9. Seasonal patterns of TOC, DSi and alkalinity in the Råneälven.

about 70 years of global annual anthropogenic $\mathrm{C}$ emissions (Gorham, 1991). Temperature increases above the global average have been predicted at high latitudes in the northern hemisphere and increases in temperature and water discharge have already been recorded in the largest Eurasian rivers (Peterson et al., 2002). Similar trends were also foreseen for the boreal and subarctic part of the Baltic Sea catchment (Graham, 2004) and the unperturbed boreal rivers of the Baltic region can be regarded as model systems for the large Siberian rivers since biogeochemical characteristics of the watersheds are similar (Humborg et al., 2004; Smedberg et al., 2006). More recently, work has focused on the role of hydrological interactions with the $\mathrm{C}$ budget of entire landscapes. It has been argued (Freeman et al., 2001; Evans et al., 2002; Tranvik et al., 2002) that a change in climate and hydrology in high latitude regions could liberate large amounts of previously inactive $\mathrm{C}$ during a prolonging thawing period as total organic C (TOC) or dissolved organic C (DOC), and new studies in Swedish lakes have shown that a great deal of this organic $\mathrm{C}$ is mineralized as $\mathrm{CO}_{2}$ (Sobek et al., 2005) or $\mathrm{CH}_{4}$ during its transport to the sea. Whereas TOC export can be described as a function of water discharge, i.e., flushing of organic rich top soils (podzols are dominating) during spring flood (Boyer et al., 1996; Smedberg et al., 2006), gaseous fluxes are also positive related to soil moisture and evapotranspiration (Walker et al., 1998) that will increase with global warming. However, even during frozen periods, streamflow is dominated by "old" groundwater. This water has percolated through the soils and is rich in dissolved solids and bicarbonate; that is derived from atmospheric $\mathrm{C}$ that has been "consumed" during chemical weathering, and is partly exported as bicarbonate to the sea, where this $\mathrm{C}$ is stored as $\mathrm{CaCO}_{3}$ for geological time. These current patterns of TOC and alkalinity fluxes (mainly bicarbonate in Swedish and Finish rivers) are exemplified by the Råneälven (Fig. 9). Note that weathering products alkalinity and DSi peak during winter when groundwater contribution to stream flow is maximum and TOC peaks during spring flow when top soils are 


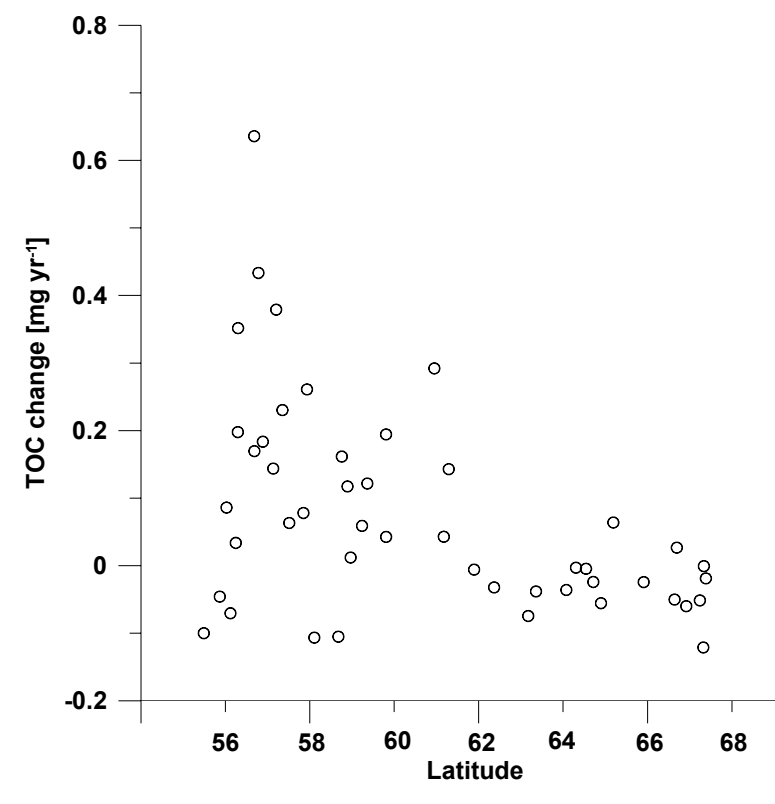

Fig. 10. Trends (30 year monthly observations) in TOC concentrations in Swedish rivers as a function of latitude.

flushed. The bicarbonate export of some wetland and coniferous forest watersheds investigated in the Baltic Sea region was between 0.4 and 1.2 tons $\mathrm{C} \mathrm{km}^{-2} \mathrm{yr}^{-1}$ corresponding to $15-73 \%$ of the TOC export (Smedberg et al., 2006). Moreover, bicarbonate export exceeds by far the $\mathrm{CO}_{2}$ outgassing in Swedish sub arctic and boreal watersheds. We roughly calculated for Sweden that about 150000 tons $C$ are leaving the aquatic systems via outgassing $\left(2.5 \mathrm{~g} \mathrm{~m}^{-2} \mathrm{yr}^{-1}\right.$ (Algesten et al., 2004) from all Swedish lakes vs. 600000 tons $\mathrm{HCO}_{3}-\mathrm{C}$ that are produced by weathering reactions between soil $\mathrm{CO}_{2}$ from respiration and mainly $\mathrm{Si}$ containing minerals and that are exported by all Swedish rivers. In other words the aquatic conduit in Sweden might be a sink for atmospheric C, not a source.

Very likely, global warming will affect water flow through the soils in taiga and tundra ecosystems (Hinzman et al., 2005) and, thus, will have an effect on watershed $C$ budgets. An increasing trend in TOC fluxes is obvious from the monthly observations of TOC concentrations at the river mouth of major Swedish rivers for the period 1980-2005 (Fig. 10). The positive trend is visible until about mid Sweden whereas the far northern watersheds do not show any change in TOC concentrations over the last 25 years. The regional patterns of this TOC increase fits with observation of an earlier ice break up in Swedish lakes (Weyhenmeyer et al., 2004) that is also confined to the southern part of Sweden. This might indicate that global warming has reached until about 62 degrees North in Sweden with respect to observed changes in hydrological patterns and river biogeochemistry. However, this TOC trend might also be related to less atmospheric deposition of $\mathrm{S}$ and $\mathrm{N}$ forming strong acids in soils and the related increase in soil $\mathrm{pH}$ that happened simultaneously. As Evans et al. (2006) reported, an increase in soil $\mathrm{pH}$, as an effect of recovery from acidification, may lead to a stronger leakage of DOC from organic rich soils. However, bicarbonate export may compensate for significant amounts of the exported TOC (as DOC or respired to $\mathrm{CO}_{2}$ and $\mathrm{CH}_{4}$ ), thereby reducing the positive feedback to atmospheric $\mathrm{CO}_{2}$. Recent simulation studies showed that the air temperatures might increase with some several ${ }^{\circ} \mathrm{Celsius}$ in the northern boreal catchment of the Baltic Sea, along with an increase in precipitation especially in the Swedish part of the watershed. This will alter the entire discharge patterns of these boreal and sub arctic watersheds with a significant higher runoff and a much prolonged spring flow starting much earlier in the season, but with a less pronounced peak flow (Graham, 2004), within the next decades. Nowadays, roughly half of the runoff in boreal and sub arctic rivers is generated within a few weeks in May and June, flushing especially topsoils that are rich in organic matter. Weathering products such as dissolved solids and alkalinity are associated mainly with groundwater (Fig. 9) and highest concentrations are measured during winter (base flow). Thus, the flow paths and transit times of waters through various landscapes and associated soil types determine the water chemistry of boreal aquatic systems and a change in these pathways can be foreseen with global warming. An increase in runoff may either flush even more topsoil leading to a massive release of organic matter or percolate deeper into soils and increasing weathering due to deeper thawing of permafrost areas. The significance of both processes for the overall $\mathrm{C}$ budgets is yet not known.

\section{Conclusions}

Probable changes in life styles, increased demand of hydropower and global warming may change the nutrient ratios in the Baltic Sea in the near future lading to improved growth conditions for mainly dinoflagellates since TN loads may increase, TP may remain at today's level or even decrease and $\mathrm{Si}$ might decrease. Thus, the N:P ratio and N:Si ratio may increase in the Baltic Sea. An increase in N:P ratios will milder the $\mathrm{N}$ limitation during spring giving room for an higher uptake of $\mathrm{P}$ in spring with lower $\mathrm{P}$ residuals for the cyanobacteria that bloom during summer (Vahtera et al., 2007). A decrease in N:Si ratios may favour non-siliceous blooms such as observed in the Black Sea and elsewhere (Humborg et al., 2000). TN loads to the Baltic will probably increase due to a change in human food consumption (more animal protein demand) that may foster higher livestock in the transitional countries of the Baltic Sea. Although the increase in TN loads may not be as high as we have foreseen in our most pessimistic scenario (an increase of 340000 tons $\mathrm{yr}^{-1}$ ) it appears obvious that a change in these diffusive emissions can hardly be compensated by a potential decrease in TN loads as 
a result of an improved sewage treatment that we estimated to be one order of magnitude lower (about 34000 tons $\mathrm{yr}^{-1}$ ) than the potential increase from livestock emissions. These latter emissions will also increase the TP loads but to a lesser extent compared to TN loads, since soil retention for $\mathrm{P}$ from manure is much higher than for $\mathrm{N}$. Thus, the potential TP increase from manure can be easily compensated by improved sewage treatment that is much more efficient for $\mathrm{P}$ compared to N. Our pessimistic scenario for the development of livestock in transitional countries revealed a TP increase of some 16000 tons $\mathrm{yr}^{-1}$ that can be compensated if the transitional countries reach the same standard in sewage cleaning as Sweden that could decrease TP emissions by the same amounts. Whether the transitional countries will have a livestock density as high as Denmark might be too pessimistic whereas the installation of tertiary cleaning of point sources is increasing with several \% per year, thus, P load might decrease significantly in the near future. That DSi loads will decrease further due to a general trend in energy policy substituting energy from fossil fuels by renewable energy sources and the enlargement of hydropower is definitely a realistic possibility in the Baltic Sea catchment. It is also likely that the riverine loads of both organic and inorganic forms of carbon (DOC and alkalinity) will increase from the boreal part of the Baltic Sea catchment, due to higher runoff and deeper soil infiltration of rain and melt water. This will increase the DOC concentration that is already high in the Baltic Sea. This, in turn, will influence significantly light conditions for phytoplankton growth and the entire food web in the Bothnian Bay and Bothnian Sea, since allochthonous organic carbon is a main energy source for the pelagic food web (Sandberg et al., 2004). Whether alkalinity may increase or decrease is difficult to evaluate, since a higher riverine input might be compensated by a potential higher freshness of the Baltic Sea when total river runoff will increase (Winsor et al., 2001).

Edited by: A. Ducharne

\section{References}

Algesten, G., Sobek, S., Bergstrom, A. K., Agren, A., Tranvik, L. J., and Jansson, M.: Role of lakes for organic carbon cycling in the boreal zone, Global Change Biol., 10, 141-147, 2004.

Berner, E. K. and Berner, R. A.: Global Environment: Water, Air and Geochemical Cycles, Prentice Hall, 1995.

Boyer, E. W., Hornberger, G. M., Bencala, K. E., and McKnight, D.: Overview of a simple model describing variation of dissolved organic carbon in an upland catchment, Ecol. Model., 86, 183188, 1996.

Boyer, E. W., Goodale, C. L., Jaworski, N. A., and Howarth, R. W.: Anthropogenic nitrogen sources and relationships to riverine nitrogen export in the northeastern USA, Biogeochemistry, 57, 137-169, 2002.

Campling, P., Terres, J. M., Walle, S. V., Van Orshoven, J., and Crouzet, P.: Estimation of nitrogen balances from agriculture for EU-15: spatialisation of estimates to river basins using the CORINE Land Cover, Phys. Chem. Earth, 30, 25-34, 2005.

Egge, J. K. and Aksnes, D. L.: Silicate as Regulating Nutrient in Phytoplankton Competition, Mar. Ecol.-Prog. Ser., 83, 281-289, 1992.

Eriksson, H., Pastuszak, M., Löfgren, S., Mörth, C.-M., and Humborg, C.: Nitrogen budgets of the Polish agriculature 1960-2000: implications for riverine nitrogen loads to the Baltic Sea from transitional countries, Biogeochemistry, 85, 153-168, 2007.

Evans, C. D., Freeman, C., Monteith, D. T., Reynolds, B., and Fenner, N.: Climate change - Terrestrial export of organic carbon Reply, Nature, 415, 862-862, 2002.

Evans, C. D., Chapman, P. J., Clark, J. M., Monteith, D. T., and Cresser, M. S.: Alternative explanations for rising dissolved organic carbon export from organic soils, Global Change Biol., 12, 2044-2053, 2006.

Freeman, C., Evans, C. D., Monteith, D. T., Reynolds, B., and Fenner, N.: Export of organic carbon from peat soils, Nature, 412, 785-785, 2001.

Gorham, E.: Northern Peatlands - Role in the Carbon-Cycle and Probable Responses to Climatic Warming, Ecol. Appl., 1, 182$195,1991$.

Graham, L. P.: Climate change effects on river flow to the Baltic Sea, Ambio, 33, 235-241, 2004.

Grant, R., Nielsen, K., and Waagepetersen, J.: Reducing nitrogen loading of inland and marine waters - Evaluation of Danish policy measures to reduce nitrogen loss from farmland, Ambio, 35, 117-123, 2006.

Haith, D. A. and Shoemaker, L. L.: Generalized Watershed Loading Functions for Stream-Flow Nutrients, Water Resour. Bull., 23, 471-478, 1987.

Hannerz, F. and Destouni, G.: Spatial characterization of the Baltic Sea Drainage Basin and its unmonitored catchments, Ambio, 35, 214-219, 2006.

HELCOM: The fourth Baltic Sea pollution load compilation (PLC4), Baltic Sea Environment Proceedings, Baltic Sea Environment Proceedings, 93, 133 pp., 2004.

Hinzman, L. D., Bettez, N. D., Bolton, W. R., Chapin, F. S., Dyurgerov, M. B., Fastie, C. L., Griffith, B., Hollister, R. D., Hope, A., Huntington, H. P., Jensen, A. M., Jia, G. J., Jorgenson, T., Kane, D. L., Klein, D. R., Kofinas, G., Lynch, A. H., Lloyd, A. H., McGuire, A. D., Nelson, F. E., Oechel, W. C., Osterkamp, T. E., Racine, C. H., Romanovsky, V. E., Stone, R. S., Stow, D. A., Sturm, M., Tweedie, C. E., Vourlitis, G. L., Walker, M. D., Walker, D. A., Webber, P. J., Welker, J. M., Winker, K., and Yoshikawa, K.: Evidence and implications of recent climate change in northern Alaska and other arctic regions, Climatic Change, 72, 251-298, 2005.

Howarth, R. W., Billen, G., Swaney, B., Townsend, A., Jaworski, N., Lajtha, K., Downing, J. A., Elmgren, R., Caraco, N., Jordan, T., Berendse, F., Freney, J., Kudeyarov, V., Murdoch, P., and Zhu Zhao, L.: Regional nitrogen budgets and riverine N \& P fluxes for the drainages to the North Atlantic Ocean: Natural and human influences, Biogeochemistry, 35, 75-139, 1996.

Humborg, C., Smedberg, E., Mörth, C.-M., Rahm, L., and Danielsson, A.: Dissolved silica dynamics in boreal and arctic rivers: vegetation control over temperature?, in: The Silicon Cycle, edited by: Ittekkot, V., Unger, D., Humborg, C., and Tac An, N., Washington DC, Island Press, 53-69, 2006a. 
Humborg, C., Conley, D. J., Rahm, L., Wulff, F., Cociasu, A., and Ittekkot, V.: Silicon retention in river basins: Far-reaching effects on biogeochemistry and aquatic food webs in coastal marine environments, Ambio, 29, 45-50, 2000.

Humborg, C., Pastuszak, M., Aigars, J., Siegmund, H., Mörth, C. M., and Ittekkot, V.: Decreased silica land-sea fluxes through damming in the Baltic Sea catchment - significance of particle trapping and hydrological alterations, Biogeochemistry, 77, 265281, 2006 b.

Humborg, C., Blomqvist, S., Avsan, E., Bergensund, Y., Smedberg, E., Brink, J., and Mörth, C. M.: Hydrological alterations with river damming in northern Sweden: Implications for weathering and river biogeochemistry, Global Biogeochem. Cy., 16, GB1039, doi:10.1029/2000GB001369, 2002.

Humborg, C., Smedberg, E., Blomqvist, S., Mörth, C. M., Brink, J., Rahm, L., Danielsson, A., and Sahlberg, J.: Nutrient variations in boreal and subarctic Swedish rivers: Landscape control of landsea fluxes, Limnol. Oceanogr., 49, 1871-1883, 2004.

Iital, A., Stålnacke, P., Deelstra, J., Loigu, E., and Pihlak, M.: Effects of large-scale changes in emissions on nutrient concentrations in Estonian rivers in the Lake Peipsi drainage basin, J. Hydrol., 304, 261-273, 2005.

Johansson, S., Bonsdorff, E., and Wulff, F.: The MARE Research Program 1999-2006 - Reflections on program management, Ambio, 36, 119-122, 2007.

Johnes, P. J., Moss, B., and Phillips, G. L.: The determination of water quality by land use, livestock numbers and population data - testing of a model for use in conservation and water quality management, Freshw. Biol., 36, 451-473, 1996.

Kronvang, B., Jeppesen, E., Conley, D. J., Sondergaard, M., Larsen, S. E., Ovesen, N. B., and Carstensen, J.: Nutrient pressures and ecological responses to nutrient loading reductions in Danish streams, lakes and coastal waters, J. Hydrol., 304, 274-288, 2005.

Lasaga, A.: Kinetic Theory in Earth Sciences, Princton University Press, 1998.

Lehner, B., Czisch, G., and Vassolo, S.: The impact of global change on the hydropower potential of Europe: a model-based analysis, Energy Policy, 33, 839-855, 2005.

Löfgren, S., Gustafson, A., Steineck, S., and Stålnacke, P.: Agricultural development and nutrient flows in the Baltic states and Sweden after 1988, Ambio, 28, 320-327, 1999.

Meybeck, M.: Pathways of major elements from land to ocean through rivers, in: River Inputs to Ocean Systems, edited by: Martin, J.-M., Burton, J. D., and Eisma, D., UNEP IOC SCOR United Nations, 18-30, 1979.

Mörth, C.-M., Humborg, C., Eriksson, E., Danielsson, A., Medina, R., Löfgren, S., Swaney, D. P., and Rahm, L.: Modeling riverine nutrient transport of the Baltic Sea-A large scale approach, Ambio, 36, 124-133, 2007.

Nixon, S. W.: Coastal Marine Eutrophication - a Definition, Social Causes, and Future Concerns, Ophelia, 41, 199-219, 1995.

Oenema, O., Boers, P. C. M., van Eerdt, M. M., Fraters, B., van der Meer, H. G., Roest, C. W. J., Schroder, J. J., and Willems, W. J.: Leaching of nitrate from agriculture to groundwater: the effect of policies and measures in the Netherlands, Environ. Pollut., 102, 471-478, 1998.

Peterson, B. J., Holmes, R. M., McClelland, J. W., Vörösmarty, C. J., Lammers, R. B., Shiklomanov, A. I., Shiklomanov, I. A., and
Rahmstorf, S.: Increasing river discharge to the Arctic Ocean, Science, 298, 2171-2173, 2002.

Rukhovets, L. A., Astrakhantsev, G. P., Menshutkin, V. V., Minina, T. R., Petrova, N. A., and Poloskov, V. N.: Development of Lake Ladoga ecosystem models: modeling of the phytoplankton succession in the eutrophication process. I, Ecol. Model., 165, 49-77, 2003.

Sandberg, J., Andersson, A., Johansson, S., and Wikner, J.: Pelagic food web structure and carbon budget in the northern Baltic Sea: potential importance of terrigenous carbon, Mar. Ecol.Prog. Ser., 268, 13-29, 2004.

Sapek, A.: The Effects of Agriculture on Water Quality: A Polish Perspective, in: Center for Agricultural and Rural Development, Iowa State University, p. 22, 1997.

Schelske, C. L., Stoermer, E. F., Conley, D. J., Robbins, J. A., and Glover, R. M.: Early eutrophication in the lower Great Lakes: New evidence from biogenic silica in sediments, Science, 222, 320-322, 1983.

Schernewski, G. and Neumann, T.: The trophic state of the Baltic Sea a century ago: a model simulation study, J. Mar. Syst., 53, 109-124, 2005.

Smedberg, E., Mörth, C. M., Swaney, D. P., and Humborg, C.: Modeling hydrology and silicon-carbon interactions in taiga and tundra biomes from a landscape perspective: Implications for global warming feedbacks, Global Biogeochem. Cy., 20, GB2014, doi:10.1029/2005GB002567, 2006.

Sobek, S., Tranvik, L. J., and Cole, J. J.: Temperature independence of carbon dioxide supersaturation in global lakes, Global Biogeochem. Cy., 19, GB2003, doi:10.1029/2005GB002567, 2006.

Stålnacke, P., Grimvall, A., Sundblad, K., and Wilander, A.: Trends in nitrogen transport in Swedish rivers, Environ. Monit. Assess., 59, 47-72, 1999a.

Stålnacke, P., Grimvall, A., Sundblad, K., and Tonderski, A.: Estimation of riverine loads of nitrogen and phosphorus to the Baltic Sea, 1970-1993, Environ. Monit. Assess., 58, 173-200, 1999b.

Stålnacke, P., Grimvall, A., Libiseller, C., Laznik, A., and Kokorite, I.: Trends in nutrient concentrations in Latvian rivers and the response to the dramatic change in agriculture, J. Hydrol., 283, 184-205, 2003.

Tranvik, L. J. and Jansson, M.: Climate change - Terrestrial export of organic carbon, Nature, 415, 861-862, 2002.

Treguer, P., Nelson, D. M., van Bennekom, A. J., Demaster, D. J., Leynaert, A., and Queguiner, B.: The silica balance in the world ocean - a reestimate, Science, 268, 375-379, 1995.

Vagstad, N., Stålnacke, P., Andersen, H. E., Deelstra, J., Jansons, V., Kyllmar, K., Loigu, E., Rekolainen, S., and Tumas, R.: Regional variations in diffuse nitrogen losses from agriculture in the Nordic and Baltic regions, Hydrol. Earth Syst. Sci., 8, 651-662, 2004, http://www.hydrol-earth-syst-sci.net/8/651/2004/.

Vahtera, E., Conley, D. J., Gustafsson, B. G., Kuosa, H., Pitkanen, H., Savchuk, O. P., Tamminen, T., Viitasalo, M., Voss, M., Wasmund, N., and Wulff, F.: Internal ecosystem feedbacks enhance nitrogen-fixing cyanobacteria blooms and complicate management in the Baltic Sea, Ambio, 36, 186-194, 2007.

Walker, D. A., Auerbach, N. A., Bockheim, J. G., Chapin, F. S., Eugster, W., King, J. Y., McFadden, J. P., Michaelson, G. J., Nelson, F. E., Oechel, W. C., Ping, C. L., Reeburg, W. S., Regli, S., Shiklomanov, N. I., and Vourlitis, G. L.: Energy and trace-gas fluxes 
across a soil pH boundary in the arctic, Nature, 394, 469-472, 1998.

Weyhenmeyer, G. A., Meili, M., and Livingstone, D. M.: Nonlinear temperature response of lake ice breakup, Geophys. Res. Lett., 31, LO7203, doi:10.1029/2004GLO19530, 2004.

Winsor, P., Rodhe, J., and Omstedt, A.: Baltic Sea ocean climate: an analysis of $100 \mathrm{yr}$ of hydrographic data with focus on the freshwater budget, Climate Res., 18, 5-15, 2001.

Witek, Z., Humborg, C., Savchuk, O., Grelowski, A., and LysiakPastuszak, E.: Nitrogen and phosphorus budgets of the Gulf of Gdansk (Baltic Sea), Estuar. Coast. Shelf Sci., 57, 239-248, 2003.
Wulff, F., Savchuk, O., Sokolov, A., Humborg, C., and Mörth, C.M.: Management options and effects on a marine ecosystem: Assessing the future of the Baltic., Ambio, 36, 243-249, 2007.

Zessner, M. and Lindtner, S.: Estimations of municipal point source pollution in the context of river basin management, Water Sci. Technol., 52, 175-182, 2005. 